\title{
Pulmonary actinomycosis: a clinical surprise!
}

\author{
Raj Kumar Mani, Vipul Mishra, Prashant Kumar Singh, Debakanta Pradhan
}

Department of Pulmonology Critical Care, Nayati Multi Super Speciality Hospital, Mathura, India

\section{Correspondence to}

Dr Raj Kumar Mani, raj.rkmjs@gmail.com

Accepted 14 January 2017

\section{DESCRIPTION}

A 65 year-old man with diabetes presented with a brief febrile illness, extreme debility and respiratory distress. X-ray chest showed a right lower lobe consolidation. A clinical diagnosis of severe community-acquired pneumonia was made for which he required antibiotics, non-invasive ventilatory support and admission to intensive care for a week. Nasopharyngeal swab was positive for influenza A by real-time PCR. The patient made apparent clinical recovery but a persisting right lower zone infiltrate. At follow-up as an outpatient 2 weeks later, he was stable haemodynamically but continued to have low-grade fever, mild hypoxia and a weight loss of $14 \mathrm{~kg}$ since illness onset. He was edentulous but had good oral hygiene. Chest X-ray (figure 1) and CT showed dense consolidation in the right lower lobe. Bronchoalveolar lavage showed non-acid fast, Gram positive, branching, filamentous bacteria, identified as actinomycetes in culture on blood agar (figure 2), while other stains and cultures were negative. Speciation of the organism was not achieved. Treatment was with intravenous ampicillin that was switched to oral dose after 1 week. Follow-up at 2 months after discharge showed marked clinical and radiological resolution.

Pulmonary actinomycosis can be a difficult condition to diagnose with delayed diagnosis or misdiagnosis being common. ${ }^{1}$ Isolated pulmonary involvement is rare. Diagnosis of actinomycosis hinges on clinicomicrobiological correlation and response to specific treatment. Viral illness and

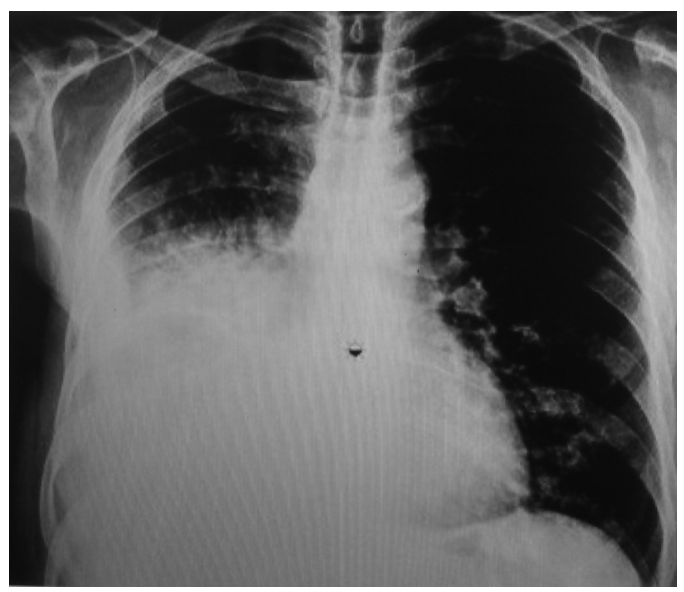

Figure 1 Chest $\mathrm{X}$-ray showing dense consolidation in the right mid and lower zones.

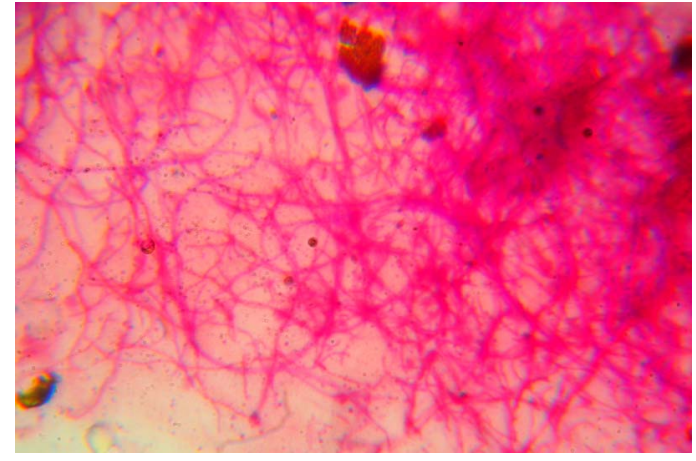

Figure 2 Bronchoalveolar lavage showed non-acid fast, Gram positive, branching, filamentous bacteria, identified as actinomycetes in culture on blood agar.

diabetes are not known to predispose to this infection; however, pathogenesis is linked to the disruption of mucosal barrier and aspiration. Actinomycosis as a cause for non-resolving pneumonia in an otherwise immunocompetent patient was a clinical surprise.

\section{Learning points}

- Pulmonary actinomycosis although rare should still be included in the differential diagnosis of non-resolving pulmonary infections.

- Diagnosis will require clinical correlation with bronchoalveolar lavage or biopsy.

Contributors RKM is the corresponding author, involved in all stages, contributed to manuscript writing and editing to the journals format, conduct, reporting, design and final approval of draft. VM involved in all stages and contributed to final editing of the manuscript, collection of data, organisation of data, obtaining patient consent and final submission online. PKS prepared the initial detailed case report write up, provided the review of literature and contributed to selecting the appropriate reference. DP is the Head of Microbiology, provided the microbiology input towards diagnosis and provided all the images, legends and information regarding the images.

Competing interests None declared.

Patient consent Obtained.

Provenance and peer review Not commissioned; externally peer reviewed.

\section{REFERENCE}

1 Mabeza GF, Macfarlane J. Pulmonary actinomycosis. Eur Respir J 2003;21:545-51. 
Copyright 2017 BMJ Publishing Group. All rights reserved. For permission to reuse any of this content visit http://group.bmj.com/group/rights-licensing/permissions.

BMJ Case Report Fellows may re-use this article for personal use and teaching without any further permission.

Become a Fellow of BMJ Case Reports today and you can:

- Submit as many cases as you like

- Enjoy fast sympathetic peer review and rapid publication of accepted articles

- Access all the published articles

- Re-use any of the published material for personal use and teaching without further permission

For information on Institutional Fellowships contact consortiasales@bmjgroup.com

Visit casereports.bmj.com for more articles like this and to become a Fellow 